\title{
DOS IMÁGENES DE MÉXICO: DE LA ÉPOCA PREHISPÁNICA A LA COLONIA
}

Solamente cuatro años separan la publicación de Visión de Anáhuac (1917) de Alfonso Reyes y Visionario de la Nueva España (1921) de Genaro Estrada. Dos momentos históricos: México a la llegada de los españoles en 1519 y México durante la época colonial del Virreinato (siglos XvI-XviII). Dos visiones, pues, del pasado nacional aparecidas en aquel momento cuando se iniciaba, tras los esplendores del modernismo por un lado y, por otro, los estragos revolucionarios, un nuevo interés por el descubrimiento de México y de lo que se entendía entonces por la esencia del alma nacional. Hacia los mismos años López Velarde, que dista mucho de ser indigenista ni colonialista, preconiza un concepto más íntimo y menos exterior de la patria al escuchar, como dice, la voz de la nacionalidad:

Han sido precisos los años del sufrimiento para concebir una patria menos externa, más modesta y probablemente más preciosa [...] nuestro concepto de la patria es hoy hacia dentro. Las rectificaciones de la experiencia [ ...] y la celebridad de nuestro republicanismo nos han revelado una patria, no histórica ni política, sino íntima ${ }^{1}$.

En el presente trabajo me propongo examinar dos imágenes del pasado mexicano, primero la descripción dada por Alfonso Reyes en Visión de Anáhuac y después la que presenta Genaro Estrada en Visionario de la Nueva España.

Distanciados geográficamente durante muchos años, Reyes y Estrada eran grandes e íntimos amigos, hermanados en estrecha

1 Ramón López Velarde, "Novedad de la patria", Obras, FCE, México, 1979, p. 232. 
amistad por una comunidad de afanes e intereses intelectuales. En el fondo lo que une a aquellos dos hombres superiores, además de la constancia en el esfuerzo cotidiano, era un humanismo vivo: el hombre en la historia y la actualidad, en el pasado y en el presente. Pertenecen, por ejemplo, a una sentida nota necrológica escrita por Reyes acerca de su compañero fallecido las siguientes palabras²:

Ha muerto a los cincuenta años, en plena labor. Debe a su propio valer, sin compromisos extraños a la excelencia misma de su trabajo, la ascensión gradual que lo llevó hasta los más altos cargos. Ni lo abatía la adversidad, gran maestra, ni lo engañaba la veleidosa fortuna. [...] Y esperó la muerte trabajando; y sigue todavía trabajando para su México, para su América, en el recuerdo de sus amigos, que son tantos en todas partes, y en la perennidad de su obra: su obra de hombre bueno, de excelente escritor y de ciudadano intachable.

En el mismo texto, tantas veces reproducido, Reyes considera a Estrada como una institución de la ciudad y hombre central en la organización intelectual de ella, figura del Renacimiento por la variedad y alcance de sus intereses, siendo "un verdadero colonizador cultural"'3. Es natural que elogie en Estrada atributos que él mismo poseía en alto grado: erudición y sabiduría, laboriosidad e ironía. Por su parte, otro gran maestro de América, Pedro Henríquez Ureña, lamenta también la ausencia de Estrada, diciendo ${ }^{4}$ :

Con Genaro Estrada (1887-1937) desaparece uno de los hombres útiles de nuestra América. Durante veinte años dio a Méjico trabajo sistemático, constructor, sin ostentación ni propaganda. Poeta y escritor, vive toda la vida espiritual de su país e interviene con actos eficaces. [...] ¡Hombre insubstituible para Méjico, incomparable para sus amigos!

Sobraría aquí toda transcripción de los infinitos tributos que exaltan el reconocido valor de Reyes como escritor y consumado hombre de letras.

El estudio de la correspondencia entre Reyes y Estrada con-

2 “Genaro Estrada", en $A R O C$, t. 12, pp. 180-181.

${ }^{3}$ Ibid., p. 180.

4 Pedro Henríquez Ureña, “In memoriam”, Sur, 1937, núm. 7, 85-86. 
firma la firme amistad recíproca que existió por mucho tiempo entre los dos escritores y diplomáticos ${ }^{5}$. Se consultaban el uno al otro en frecuentes ocasiones y sobre muchos asuntos de diversa índole; desde Buenos Aires Reyes pedía al amigo colaboraciones para distintas revistas y, a su vez, correspondiendo a las repetidas invitaciones de Estrada, envía Reyes páginas para Contemporáneos, Hoy y otras publicaciones de México. El nutrido epistolario evidencia un apoyo mutuo en sus proyectos literarios y profesionales. De una carta de Estrada del 10 de marzo de 1928 transcribo como botón de muestra un breve fragmento:

Sé también que usted es la mejor figura literaria que ha producido México, incluidas todas las glorias de antología, sé que dentro de más o menos años no habrá quien me niegue mi opinión, y sé, sobre todo, que he tenido la suerte de ser su amigo, y que esto ya nadie me lo quita ${ }^{6}$.

\section{DOS SEMBLANZAS INCOMPLETAS: REYES Y ESTRADA}

A estas alturas es casi imposible decir algo nuevo sobre el magisterio de Alfonso Reyes, prodigioso escritor para quien no hay nada que no le interese. Todo es digno de estudio. Tal vez cabe insistir una vez más, en el presente contexto, en la profunda dimensión mexicana de la obra alfonsina dentro del proverbial universalismo siempre asociado con Reyes: "Nada puede sernos ajeno - escribe - sino lo que ignoramos. La única manera de ser provechosamente nacional consiste en ser generosamente universal, pues nunca la parte se entendió sin el todo" ". La presencia mexicana persiste en su obra, a pesar de largas ausencias del país, e influye

5 Florence Olivier, "Correspondance entre Alfonso Reyes et Genaro Estrada', L'Ordinaire du Mexicainiste, 1981, núms. 54, 55 y 56, 7-39, 10-64 y 25-49.

6 Ibid., pp. 28-29.

7 “A vuelta de correo", en $A R O C$, t. 8, p. 439. El mismo texto no sólo es una defensa de la persistencia de México en su obra ("he publicado muchos libros de prosa y unos pocos de versos. Quien tuviera la paciencia de examinarlos, fácilmente se convencería de que no hay uno solo en que no aparezcan el recuerdo, la preocupación o la discusión directa del tema México", p. 428) frente al reproche injusto de alejamiento lanzado por Pérez Martínez, sino que también constituye un análisis de lo nacional en el arte y un inteligente comentario sobre su propia vocación constante. No resisto la tentación de copiar aquí las siguientes palabras de Reyes: "[ . . . tampoco hay que figu- 
sin duda en sus sostenidos esfuerzos para extender un puente entre la cultura europea y la americana. Hombre íntegro y dotado de una singular capacidad intelectual, combina con la seriedad una tolerancia y bondad poco comunes, revelando en todo momento una extraordinaria cordialidad humana. Además, cuanto escribe Reyes, en verso o en prosa, está tocado por la varita mágica de la verdadera poesía; flexibiliza y renueva las formas artísticas, dándoles inusitado brillo personal; y en ese proceso equilibrado entre la libertad y la disciplina logra prescindir de los viejos cánones para crear su propia personalidad. Abraza la filosofía de la intuición y acoge el impulso vital, según Henríquez Ureña, pero no se confía solamente a ellos, y resiste sin sucumbir a la fascinación del irracionalismo ${ }^{8}$. Para Reyes, la tarea de escribir es atender la llamada de la fantasía y de la realidad, plasmadas en una unidad original debida a la plenitud de sus recursos de artista y pensador ${ }^{9}$.

En el caso de Estrada, quizá sea menos temerario de mi parte ofrecer unas rápidas precisiones sobre el hombre y el escritor. Por no haber llegado todavía a la capital, no era ateneísta aunque en más de un sentido prolongó la obra intelectual de tan destacada agrupación ${ }^{10}$. Su obra, menos vasta y menos enciclopédica que la de Reyes, es sin embargo sustanciosa, en especial, si se toman en cuenta sus textos sobre temas de la diplomacia e historia de

rarse que sólo es mexicano lo folklórico, lo costumbrista o lo pintoresco. Todo esto es muy agradable y tiene derecho a vivir, pero ni es todo lo mexicano, ni es siquiera lo esencialmente mexicano. La realidad de lo nacional reside en una intimidad psicológica, involuntaria e indefinible por lo pronto, porque está en vías de clarificación. No hay que interrumpir esta química secreta. Calma y tiempo son menester. Es algo que estamos fabricando entre todos. Nunca puede uno sospechar dónde late el pulso mexicano" (pp. 441-442).

8 Pedro Henríquez Ureña, "Alfonso Reyes", en Páginas sobre Alfonso Reyes, Universidad de Nuevo León, Monterrey, 1955, t. 1, p. 154.

9 Entre los frecuentes testimonios alfonsinos en torno a sus fines y propósitos al escribir, así como su ideal ético y estético, destaco aquí solamente uno de ellos: "Respuestas", $A R O C$, t. 4, pp. 450-452.

10 Sobre esta época y la Generación del Ateneo son imprescindibles las páginas de Pasado inmediato (AROC, t. 12, pp. 182-216), en las cuales Reyes reseña los ideales intelectuales de aquel grupo de escritores y pensadores, que dejaron profundas huellas en la renovación cultural iniciada hacia 1909. En síntesis, se difundió entre la juventud intelectual un afán humanístico y los escritores se universalizaron, asomándose a las literaturas extranjeras. Reyes describe las distintas fases de sus campañas (especialmente en las pp. 202-216) destinadas a establecer las bases serias y disciplinadas de ese verdadero renacimiento en pleno siglo $\mathbf{x x}$. 
México. Su producción exclusivamente literaria es reducida (cuatro delgados volúmenes de versos, una colección de viñetas o estampas coloniales, y una especie de novela), pero imponente es su aporte en materia de bibliografía, arte e historia. Era, por supuesto, incansable como organizador y director de colecciones eruditas o monografías históricas. No desdeña tampoco la labor de editor y crítico. De primera fila es, por ejemplo, su primer libro, una antología de los Poetas nuevos de México (1916), guía obligatoria para los estudiosos de la poesía mexicana en las primeras décadas del siglo $\mathrm{xx}^{11}$. Además Estrada era coleccionista y anticuario, bibliófilo de reconocida fama y experto en las artes tipográficas de la imprenta. Desde joven perfecciona además su dominio de las ciencias historiográficas trabajando al lado de Genaro García. A pesar de sus afanes de anticuario, compartidos con su protagonista Pero Galín en la novela del mismo título, no pierde nunca su contacto directo con la vida moderna. Desde el Ministerio de Relaciones Exteriores, servicio en que alcanza los más altos puestos, ayuda generosamente a los jóvenes, y por este apoyo e intervención económica se mantiene por algún tiempo la revista Contemporáneos. Estrada fue, pues, una presencia significativa en México durante más de veinte años, laborando silenciosamente y con tesón en pro de la vida cultural del país. Al terminar esta breve semblanza de Estrada, es preciso notar que todos sus amigos llaman la atención sobre su carácter abierto y festivo. Poco solemne, era un hombre simpático como Reyes, burlón e irónico, cuya apariencia física ha sido captada con toda fidelidad, por lo visto, en los siguientes párrafos debidos a Fernández MacGregori2:

Era entonces rotundo, de lucios, mondos y regordetes carrillos, entre los que se escondía la boca sensual, fruncida un tanto como para emitir un soplo. Los redondos y gruesos cristales enarillados de sus lentes hacían pequeños sus ojos miopes de color castaño, como su pelo, que era asaz ralo. El corte de su cara era un poco ovino, con la frente amplia y huyente, desde los pronunciados arcos

11 Alfonso Reyes no escatima sus elogios de la antología preparada por Estrada: en un momento la califica de "insustituible" (AROC, t. 8, p. 33), y parece que Estrada acogió la idea de Reyes para organizar a los poetas en torno a las tres revistas (Revista Azul, Revista Moderna, Savia Moderna), cf. AROC, t. 4, p. 301 n. Más detenido es otro comentario (AROC, t. 7, p. 474), en que Reyes dice categóricamente que "es hasta hoy, la más seriamente elaborada de cuantas existen en México".

12 Genaro Fernández MacGregor, Genaro Estrada, Fábula, México, 1938, p. 8. 
supraciliares; la nariz era corva y de móviles aletas; el mentoncillo entre mofletes y papada.

Su cuerpo, de mediana estatura, era obeso. Pero aquella figura esférica se movía, a pesar de todo, rápidamente, y su andar, a pequeños pasos, parecía un desliz, acompasado por algún tema musical tarareado en sordina.

[... ] un tipo de cardenal romano del quinientos; un orondo prelado de los que sabían exprimir de la vida los más exquisitos jugos; un amante de la cultura en todas sus manifestaciones.

En efecto, la gracia es sin duda alguna el denominador común de su obra de narrador. En una feliz aproximación al hombre y escritor, Xavier Villaurrutia, por su parte, lo caracteriza como un Des Esseintes sano, sin ridículos diabolismos, porque ambos coinciden en sus preferencias de bibliófilo y bibliógrafo, así como en su pasión por un tipo de literatura refinada. Es para Villaurrutia "una de las pocas personas de México capaces de dorar tortugas"'13. Así trabajaba sistemáticamente Estrada, sin alardes de ninguna clase y, movido por nobles anhelos, amén de sus sacrificios personales, se entregaba a la tarea de promover todo aspecto de la cultura y la historia mexicanas.

\section{Aproximación a VISIÓN DE ANÁHUAC}

Obra de juventud pero no menos perfecta por eso: ¡que no se toque! dice Reyes en su carta testamentaria dirigida a Enrique DíezCanedo y Genaro Estrada ${ }^{14}$. Singularmente predilecta de los lectores y comentaristas de Reyes, Visión de Anáhuac ha tenido amplísima fortuna bibliográfica. Ha sido varias veces traducida a diferentes lenguas y frecuentemente editada, inclusive en precioso volumen de la Biblioteca Índice, preparado bajo la dirección y gusto exigente de Juan Ramón Jiménez (1923). En fin, pieza obligatoria de antología. ¿Qué es lo que ha escapado a los exégetas de tan popular texto? Supongo que poco, pero me contento aquí con estampar algunas impresiones de devoto y asiduo lector, superando mi natural temor a repeticiones y redundancias inútiles.

La bella y transparente prosa de Visión de Anáhuac ejemplifica claramente una constante de la obra de Alfonso Reyes: la fusión de inteligencia y sensibilidad, del saber y del sentir. Es decir, la

13 Xavier Villaurrutia, “Pero Galín”, en Textos y pretextos, La Casa de España en México, México, 1940, pp. 74-75.

$14 A R O C$, t. 4 , p. 477. 
erudición se transforma en arte y, en este caso, un arte seguramente influido por la tensión espiritual producida por la nostalgia y la añoranza. El autor no hace esperar al lector. En la primera página del texto ${ }^{15}$ Reyes afirma que en la época de los descubrimientos la historiografía ha cambiado, desbordándose del cauce clásico ("el hecho político cede el puesto a los discursos etnográficos y a la pintura de civilizaciones"', p. 13). El punto de partida es la recopilación de Giovanni Battista Ramusio (1550), en tres tomos. Casi de inmediato se dibujan las candorosas estampas que decoran la obra:

[...] barcos diminutos se deslizan por una raya que cruza el mar; en pleno océano, se retuerce, como cuerno de cazador, un monstruo marino, y en el ángulo irradia picos una fabulosa estrella náutica. Desde el seno de la nube esquemática, sopla un Eolo mofletudo, indicando el rumbo de los vientos - constante cuidado de los hijos de Ulises. Vense pasos de la vida africana, bajo la tradicional palmera y junto al cono pajizo de la choza, siempre humeante; hombres y fieras de otros climas, minuciosos panoramas, plantas exóticas y soñadas islas (p. 13).

Finalmente las estampas que aparecen en los libros de Ramusio describen también la vegetación de Anáhuac: "un nuevo arte de naturaleza" (p. 14). Aquí y en lo que sigue inmediatamente la prosa de Reyes, siempre rica en imaginación, llega a tener la modulación de la más auténtica poesía, y Visión de Anáhuac confirma desde un primer instante cómo consigue hasta en sus ensayos y textos críticos una tensión lírica.

Antes de la redacción de estas páginas, escritas en 1915 cuando residía en el extranjero y lejos de la patria, Reyes había estudiado las relaciones entre la poesía mexicana y el ambiente físico del país. Advierte, por ejemplo, en su conferencia de 1910 que Othón, en los Poemas rústicos, contemplaba de modo directo las bellezas naturales del paisaje mexicano, pero, más allá de la mera descripción de ellas, ese acto contemplativo tenía raíz trascendental, porque se resolvía en una interpretación mística del mundo ${ }^{16}$. Sin embargo, el antecedente más significativo en el presente contexto es El paisaje en la poesía mexicana del siglo XIX (1911), y se nota en seguida que algunas páginas e ideas del folleto pasa-

15 Todas las citas de Visión de Anáhuac corresponden a $A R O C$, t. 2, pp. 13-34.

16 “Los Poemas rústicos de Manuel José Othón”, en AROC, t. 1, pp. 175-192. 
ron a Visión de Anáhuac, apenas modificadas, como puede comprobarse con facilidad. En esta obra Reyes se propone estudiar cómo los poetas mexicanos interpretaron la naturaleza, y afirma en un principio que el paisaje "es lo más nuestro que tenemos",17. Claro que las maravillas del nuevo continente eran para los escritores europeos un constante motivo de asombro y admiración; se refiere Reyes a las dos tradiciones, la española y la indígena, que con el tiempo se funden en el ser mexicano. La naturaleza, pues, es fuente de poesía y, con palabras que serán repetidas después, Reyes apunta que lo más original de esa visión es: " [. . . ] junto con el raro aspecto de la vegetación indígena, la extremada nitidez del aire, el brillo inusitado de los colores, la despejada atmósfera en que se destacan, vigorosos, todos los elementos de nuestro paisaje"'18.

Nadie duda, por supuesto, de la profunda y acendrada mexicanidad de Alfonso Reyes, asunto que le obligó una vez a una razonada defensa cuando fue acusado de desvinculación nacional ${ }^{19}$. Solamente se menciona este hecho porque Visión de Anáhuac es un texto explícitamente mexicano y también porque, en una carta a Antonio Mediz-Bolio (1922), Reyes afirma que ha soñado con la idea de escribir una serie de ensayos bajo la divisa "en busca del alma nacional', y prosigue ${ }^{20}$ :

La Visión de Anáhuac puede considerarse como un primer capítulo de esta obra, en la que yo procuraría extraer e interpretar la moraleja de nuestra terrible fábula histórica: buscar el pulso de la patria en todos los momentos y en todos los hombres en que parece haberse intensificado; pedir a la brutalidad de los hechos un sentido espiritual; descubrir la misión del hombre mexicano en la tierra, interrogando pertinazmente a todos los fantasmas y las piedras de nuestras tumbas y nuestros monumentos. Un pueblo se salva cuando logra vislumbrar el mensaje que ha traído al mundo: cuando logra electrizarse hacia un polo, bien sea real o imaginario, porque de lo real y lo imaginario está tramada la vida.

En último análisis, piensa Reyes que hallar y precisar esa unidad espiritual será un paso previo para la comprensión total del país, ofreciendo al mismo tiempo una posible respuesta para conseguir la resolución de los problemas nacionales.

17 AROC, t. 1, p. 195.

18 Ibid., pp. 196-197.

19 Véase supra, nota 7.

20 "Carta a Antonio Mediz-Bolio", en AROC, t. 4, p. 421. 
En Visión de Anáhuac Reyes, desde lejos, se ha proyectado afectivamente sobre el pasado, captando la tradición bella de la herencia indígena, y se entrega a la contemplación amorosa del paisaje mexicano. A partir de la palabra inicial del título - palabra que sugiere lo propio y lo subjetivo- estamos ya en la antesala de la poesía y, por encima de las múltiples fuentes literarias y artísticas, se impone siempre la auténtica emoción experimentada por Reyes al describir los prodigios de aquel mundo encantado. El testimonio de los cronistas y los poetas se funde con la imaginación del escritor. En efecto, la fuente no estorba nunca, sino que enriquece el texto alfonsino.

Así es que en estas breves páginas se oyen dos voces que se compenetran íntimamente: la del poeta y la del ensayista. Creo que por acuerdo tácito todos clasificaríamos Visión de Anáhuac como ensayo lírico o poema en prosa con sobretonos de ensayo. Cada una de las cuatro divisiones textuales, así como los respectivos epígrafes, tienen una función específica que confiere al conjunto una bien trabada y armoniosa arquitectura. Desde luego, la parte final y más breve expone la teoría y la doctrina, conceptos e ideas que han influido en la movida descripción anterior de la vegetación del Valle de México y el modo de ser y de vivir de sus habitantes primitivos. A modo de resumen, en la cuarta parte Reyes destaca otra vez la belleza de la civilización indígena de antaño, y subraya cómo la raza de hoy se nutre siempre de su propio pasado. Además de la comunidad de sangre y de esfuerzos mutuos, existe un alma común que se afirma principalmente en dos sentimientos unificadores: "la emoción cotidiana ante el mismo objeto" y "la emoción histórica", que son a su vez parte integral de la vida actual e innegable móvil creador. Y con una doble admonición se cierra la obra: no renunciar a ningún objeto de belleza (Keats) ni tampoco a las leyendas o mitologías indígenas (p. 34).

Ahora es necesario decir, en apretada síntesis, algo más específico sobre el estilo y la riqueza expresiva de la Visión de Anáhuac, páginas escritas con una elaborada y exuberante prosa, que logra describir con notable éxito todo el espectáculo de Anáhuac y Tenochtitlan en 1519. A propósito he dicho espectáculo, pero recordemos que más de una vez el texto ha sido comparado con la vasta pintura mural de Diego Rivera en el Palacio Nacional, comparación sin duda acertada por las vistas panorámicas junto con las pinceladas que hacen resaltar en el espacio los pequeños detalles. En la efusión descriptiva, no obstante, siempre prevalece la imaginación de Reyes, visible tanto en finas estilizaciones como en 
sugestivas imágenes de toda clase. También al describir la vegetación de la Meseta Central y al exaltar el pasado en los principales sitios de la vida de la ciudad (templo, mercado, palacio) se vale a menudo de aptas analogías, comparando todo aquello primero con Castilla y luego con las viejas civilizaciones de la antigüedad (Babilonia, Egipto, Constantinopla, Roma).

Se trata en el fondo de una fiesta de colores y de sonidos, destacándose de manera especial la luz y su fulgor en la transparencia del aire ${ }^{21}$. Las cosas sí, pero primordialmente la sensación de las cosas. Esa sensualidad descriptiva, de tipo impresionista, llega tal vez al punto más alto en la evocación de la plaza vista como "un mareo de los sentidos, como un sueño de Breughel, donde las alegorías de la materia cobran un calor espiritual" (p. 22). Las rápidas enumeraciones que apelan fundamentalmente a los sentidos en este fragmento no tienen desperdicio, y la descripción acaba con la siguiente imagen enérgica:

Entre las vasijas morenas se pierden los senos de la vendedora. Sus brazos corren por entre el barro como en su elemento nativo: forman asas a los jarrones y culebrean por los cuellos rojizos. Hay, en la cintura de las tinajas, unos vivos de negro y oro que recuerdan el collar ceñido a su garganta. Las anchas ollas parecen haberse sentado, como la india, con las rodillas pegadas y los pies paralelos (p. 22).

Con una metamorfosis metafórica, la vendedora ha sido totalmente asimilada a su mercancía y, al verla fundida con las vasijas, el ajo del escritor percibe por encima de todo las formas y contornos de las cosas. Esa misma plasticidad de la expresión es un elemento constante de sus modos expresivos, como atestiguan los siguientes ejemplos:

[...] pero, sobre todo, las plantas típicas: la biznaga mexicana - imagen del tímido puerco espín-, el maguey (del cual se nos dice que sorbe sus jugos a la roca), el maguey que se abre a flor de tierra, lanzando a los aires su plumero; los "órganos" paralelos, unidos como las cañas de la flauta y útiles para señalar la linde; los discos del nopal - semejanza del candelabro-, conjugados en una superposición necesaria, grata a los ojos: todo ello nos aparece como una flora emblemática, y todo como concebido para blasonar

21 Ha sido estudiado el tema del resplandor y claridad de la luz, con todas sus variantes, por James Willis RoBb, El estilo de Alfonso Reyes. Imagen y estructura, $2^{a}$ ed., FCE, México, 1978, pp. 84 ss. 
un escudo. En los agudos contornos de la estampa, fruto y hoja, tallo y raíz, son caras abstractas, sin color que turbe su nitidez (p. 14).

La visión más propia de nuestra naturaleza está en las regiones de la mesa central: allí la vegetación arisca y heráldica, el paisaje organizado, la atmósfera de extremada nitidez, en que los colores mismos se ahogan - compensándolo la armonía general del dibujo; el éter luminoso en que se adelantan las cosas con un resalte individual [...] (p. 16).

También en la tercera parte del texto, dedicada a la flor ("signo de lo noble y lo precioso", p. 28) ${ }^{22}$ y la poesía indígena, las plantas y las flores se describen con parecidas técnicas pictóricas:

La flor se pinta de un modo esquemático, reducida a estricta simetría, ya vista por el perfil o ya por la boca de la corola. Igualmente, para la representación del árbol se usa de un esquema definido: ya es un tronco que se abre en tres ramas iguales rematando en haces de hojas, o ya son dos troncos divergentes que se ramifican de un modo simétrico (p. 28).

Por último, quisiera insistir de nuevo en la manifiesta riqueza expresiva de Visión de Anáhuac, riqueza apenas aludida en la presente nota, y en la voluntad de estilo que caracteriza sus más bellas páginas. Como se dijo ya, se trata de un enorme fresco, pero no debe perderse de vista el hecho de que Reyes al mismo tiempo se encariña con lo pequeño y, con esos detalles mínimos, se construye poco a poco la totalidad del cuadro ${ }^{23}$. Creo que su máximo acierto fue saber fundir, en compleja y feliz combinación, las fuentes librescas con una nueva visión imaginativa del Nuevo

22 Sobre las flores Francisco Monterde ("Prólogo", Visión de An'áhuac, Cultura Mexicana, México, 1962, pp. 15-35) ha escrito: “[ . .. ] se arriba finalmente al culto de la flor: por ella, el indígena del Anáhuac se distingue de otros artífices de la América prehispánica. [...] El hombre de la altiplanicie mexicana evoca a cada instante la flor; hace de ella un símbolo: la flor es la poesía y es también la herida causada por la guerra, la guerra sagrada, florida. El poeta va en busca de flores, que eterniza en los cantos: a pesar de todo lo arrasado, persisten sus huellas en los manuscritos de las cuales trasciende aún el perfume floral, que extrajeron de las pinturas quienes los trazaron" (pp. 30-31).

23 Raúl Silva Castro, "Notas de Alfonso Reyes", en Páginas sobre Alfonso Reyes, t. 1, p. 251, ha visto también esa conjugación de lo grande y lo minúsculo, diciendo: “Este breve libro produce alternativamente la impresión de ser vasto fresco de la primitiva vida mexicana, en los días primeros de la conquista española, y también la de ser un relicario de miniaturas". 
Mundo y sus pobladores. Al finalizar el presente comentario ${ }^{24}$, necesariamente parcial e incompleto, me parecen muy certeras las palabras de Federico de Onís sobre Visión de Anáhuac, y las transcribo ahora ${ }^{25}$ :

Y a México dedicó una de sus primeras obras [ . . ] muestra bellísima del arte de Alfonso Reyes para fundir el saber histórico y la poesía al reconstruir el alba del México moderno, el momento inicial del cruzamiento del mundo europeo con la civilización azteca, que aparece ante nuestros ojos deslumhrados - como ante los de los conquistadores españoles- pura, límpida y desrealizada, como una realidad poética en la que se siente la altura de la meseta mexicana y se ven las cosas en la transparencia única de su atmósfera. No es una reconstrucción histórica en sí misma, sino la visión que resulta del cruzamiento sutil del mundo precortesiano con la mirada del hombre de fuera, del viajero de antes o de hoy que llega a "la región más transparente del aire".

En torno al Visionario de LA NUEVA España

vino a ser como un Gaspar de la noche mexicano y no creo que antes de él se haya logrado poner a contribución, con mejor efecto, todos los temas y motivos de nuestra imaginería colonial, de nuestra suntuosa y parsimoniosa “Edad Media», llena de virreyes, frailes y doctores, asuntos transportados por él a un ambiente, si vale decirlo, de disciplinada fantasía, de ensueño con bridas.

ALFONSO REYEs ${ }^{26}$

Pasamos ahora a examinar el libro Visionario de la Nueva España de Genaro Estrada, cuyo subtítulo de "fantasías mexicanas" pro-

24 A última hora he podido consultar la parte de Historia documental de mis libros (UMx, 1955, núm. 8, 7-10) que corresponde a Visión de Anáhuac. Aquí Reyes se refiere brevemente a la génesis de la obra, y da un gran acopio de precisiones bibliográficas sobre el texto y sus ediciones, inclusive las traducciones a diferentes lenguas. Habla también de sus fuentes principales, viejas y modernas, y transcribe una serie numerosa de juicios y elogios, de la más variada procedencia, acerca de la segunda edición (la de Índice, 1923). Esas páginas me parecen imprescindibles para completar la historia de Visión de Anáhuac, y por tanto recojo el dato ahora.

25 Federico de Onís, "Alfonso Reyes", Páginas sobre Alfonso Reyes, t. 2, p. 129.

26 "Genaro Estrada", en $A R O C$, t. 12, p. 177. 
porciona al lector una clave previa para entrar en aquel mundo lejano e idealizado del Virreinato ${ }^{27}$. El siguiente epígrafe tomado del "Bateau ivre" de Rimbaud confirma el aspecto visionario de las breves estampas de la obra: "Et j' ai vu quelquefois / ce que l'homme a cru voir". El intento de Estrada es, por supuesto, la reconstrucción de aquel pasado (costumbres, prácticas, ambientes, lugares, acciones características y estados de ánimo), y lo hace manteniendo fidelidad a la erudición sin sacrificar la visión personal. Otra vez poesía e historia felizmente fundidas: invención y sabiduría. Mundo fantasmagórico sí, pero recreado a través de los nada superficiales conocimientos de la realidad de aquella sociedad cerrada e inmóvil, estructurada según rígidos principios religiosos. Sin embargo, en más de un instante se oye la inevitable voz moderna que revive y asesora el pasado colonial con criterios de actualidad. Un breve ejemplo, el de la vieja casa colonial: "Tezontle poroso que guarda las voces de los duros capitanes del siglo xvi y los gritos victoriosos de los revolucionarios del siglo $\mathrm{xx}^{28}$.

La prosa del Visionario, sugestiva y evocadora, es la de un artesano paciente empeñado en la fabricación de bellas minuciosidades artísticas, alcanzando no pocas veces un tono fundamentalmente poético, a medida que procede a la recreación de aquella realidad. Si bien a la prosa de Estrada le falta el empuje dinámico de Reyes, su obra no es de ninguna manera inerte, aun-

27 Genaro Estrada, Visionario de la Nueva España, México Moderno, México, 1921. Todas las citas que se hacen en el presente trabajo corresponden a esta edición, la primera. Ha habido una segunda edición popular de $E l$ [ $s i c$ ] Visionario de la Nueva España (Departamento del Distrito Federal, México, 1975), libro de reducido formato y destinado a la divulgación cultural. Lleva un breve y poco útil prólogo de Irma Gudiño (pp. 9-17). Acerca del Visionario MAría del CARMEN Millán ha escrito certeras palabras: "Presenta con primor de miniaturista, de minucioso artífice, pequeños cuadros que valen por su pulimiento y autenticidad tanto como por el tono de los comentarios que entre líneas reconstruyen mejor que la descripción o el diálogo, el más profundo sentido de su personal visión del mundo que reconstruye" ("Prólogo" a Pero Galín, INBA, México, 1967, p. xxii. Además relaciona el libro de Estrada con Gaspard de la nuit de Aloysius Bertrand, "precursor de la poesía moderna y maestro de Baudelaire y Mallarmé, creador de una prosa poética cuidada y armoniosa"' (ibid.).

28 "La casa", p. 191. En otro momento, Estrada se refiere a las capas de pintura que cubren la estatuilla de San Cayetano: "[ . . . la cal blanca de 1620; el ocre de 1680; el azul violento del siglo XviI, el verde claro de la independencia, el amarillo de la Reforma, el gris, el rojo, el cobalto de la época de las revoluciones"' ("El nicho", p. 175). 
que su ritmo suele ser más pausado, cadencioso y lento, como lo exigía el tema escogido.

En cierto sentido puede decirse que la obra de Estrada es un viaje imaginario por el mundo colonial o sencillamente un recorrido de la ciudad. En el primer fragmento de la obra ("Dilucidaciones", pp. 13-17) unos amigos se reúnen con el autor en amable plática sobre su nueva pasión por la vieja ciudad de México. Uno es cuentista y su arte se caracteriza en términos que también recuerdan al mismo Estrada:

Gusta de evocar las cosas de antaño y de encontrarles sutiles relaciones con las de ahora. Como su estatura, sus escritos son breves y encierra en ellos, cual en pequeños vasos preciosos, la esencia de su espíritu que ama las delicadezas, los matices, las alusiones veladas y lejanas, los labrados de los viejos muebles evocadores, las telas chafadas por la tradición, las portadas en que amontona el arte bárbaro en hojarascas indescriptibles. Su ideal sería escribir una novela sobre el breve tema de una miniatura del siglo xviI o del pañuelo de encajes de una virreina (p. 13).

El ensayista, espíritu selecto y amante de la elegancia, es "como un frasco que encierra los más suaves y delicados perfumes de la vida y el arte" (p. 14), mientras que el poeta, de alma abierta a todas las incitaciones, se conmueve en forma lírica ante las cosas. Huyendo de la vida moderna los cuatro salen a recorrer los viejos barrios de la ciudad, y ya tienen un bien planeado programa estético:

Encontramos con que la tradición de México, casi siempre libresca y fantasmagórica, es realmente bella y profundamente humana y que la ciudad encierra, íntegramente, el alma de los siglos, a la cual sólo se puede llegar por el entusiasmo y la comprensión, para aspirar cabalmente la esencia que se oculta en sus sitios recónditos y darla convertida en expresión artística, con la clara visión de los verdaderos elementos que se escapan a los ojos que no saben ver el misterio de lo maravilloso (p. 16).

Ése es entonces el evangelio del Visionario colonialista que nos lleva de la mano por aquel mundo del pasado.

Figuran en las estampas del libro los tipos más característicos de la Colonia. En el plano aristocrático, se destacan virreyes y virreinas, así como otros nobles de la corte, y pululan los religio- 
sos de las más variadas jerarquías en aquel ambiente dominado en gran parte por la Iglesia. No faltan tampoco personas de menos alcurnia: el barbero, el espadero, el organista y el mendigo. Como veremos, reserva Estrada sus máximas burlas para el sabio y el erudito. Se cuentan chismes de la corte virreinal e intriguillas a veces solamente insinuadas ("La virreina", pp. 83-84). No puede faltar la anécdota amorosa, apenas desarrollada en la sugestiva prosa "El biombo" (pp. 59-60), y tiene gracia la historieta del paje, rubio e inocente, que no advierte la belleza de la enamorada hija del visorrey, "quien debajo de su velo de blonda negra de Valencia, se ha encendido súbitamente y está a punto de tirarle del balandrán y llevarlo hasta el patiecillo de la sacristía, que ella se sabe, para declararle su amor"' (p. 162).

Pasan furtivamente en estas páginas personas reales como Francisco Cervantes de Salazar, Sigüenza y Góngora, José Churriguera, Manuel Tolsá y hasta Fernández de Lizardi en la galería de los más reconocibles. Y por supuesto, ¡no puede estar ausente Sor Juana! Un capitulillo entero (pp. 63-65) se dedica a Bernal Díaz en su vejez, dictando en voz débil a su mujer parte de su historia. Se acuerda el viejo soldado con toda claridad de los episodios de la conquista, y vuelve a ver a sus compañeros de armas, quienes le sonreían desde el cielo. Estrada se imagina el instante en que muere el cronista con esas visiones ante los ojos: "Y mientras que aquella tarde triste desvanecía sus luces en el muro de enfrente, que el musgo hacía más desolado, Bernal Díaz del Castillo sentía que un guantelete de hierro apretaba su corazón, como una esponja sangrienta"' (p. 65).

Estrada atiende también con atención especial el movimiento bullicioso de la calle y las plazas sin individualizar a otras personas típicas: los indios, frailes, mercaderes, alguaciles y alcahuetas que desfilan por la ciudad. Leamos el siguiente texto en que se habla, en primera persona, del movimiento de grupos en masa:

... encontréme de pronto en la gran plaza, rodeado de una multitud que se apretaba entre gritos, empellones, ofertas y risotadas; y caminando a trancos, rodeado de indios, vagabundos y gentes de todas condiciones, a poco doy en tierra al pretender saltar por sobre los vendedores de frutas, baratijas y fritangas, quienes sentados a la turca, a la sombra de esterillas de petates sostenidas por groseros mecanismos de paragüería, extendíanse desde los muros del $\mathrm{Pa}$ rián hasta la barda de madera de la catedral y allegábanse en grupos abigarrados, hasta la ridícula columna de Carlos VI [sic], los 
andamios que rodean la picota y la fuente de tazón, en donde se llenan los cántaros de los aguadores, limpian sus corambres los pulqueros, los perros de la calle calman la sed y las daifas se enjugan el pecho (p. 156).

En otra parte ("El pregón", pp. 95-97) la chusma oye el pregón callejero en que se detallan absurdamente las exageradas penas que sufrirá el reo acusado de traición y lesa majestad, y luego se lee: "Y el pregón seguía su paso con fingida gravedad y harta lentitud, con el Alguacil Mayor a la cabeza, que se tostaba al sol como un insignificante pollo...' (p. 97). Otra modalidad estilística del Visionario digna de ser mencionada en el presente contexto es la profusión barroca en las largas enumeraciones, las cuales permiten al autor demostrar sus vastos conocimientos de la época. Un excelente ejemplo de este procedimiento podría ser la demorada descripción de las infinitas torres de la ciudad, vistas desde una altura, a la cual sigue después una nómina pormenorizada de las cúpulas visibles desde arriba. También en otro momento todo el movimiento del arte barroco se representa eficazmente con un lujo de detalles arquitectónicos en el capitulillo ' $\mathrm{El}$ altar churrigueresco"' (pp. 77-78).

Es natural que se entretenga el colonialista en las descripciones de los viejos edificios, principalmente de los palacios e iglesias de variada categoría. Por ejemplo, Estrada describe la catedral por medio de una prosa exclamativa, deleitándose en los detalles precisos:

...que es blanca con el sol, rosada por la tarde y negra en el crepúsculo. Mírala desde el portón central del Palacio a esta hora del ángelus, ¡ cómo se destacan los cadalsos de sus torres, cómo se recortan contra la luz sus columnas de piedra, qué bien se perfilan en el azul profundo de la tarde sus remates redondos, sus balaustradas ligeras, sus ménsulas enrolladas, la cúpula que corona una jaula cubierta por los gajos blancos y azules de mayólicas, las solemnes campanas de piedra que terminan sus torres, los globos que rematan las campanas, las cruces que se erigen sobre los globos! (p. 118).

Se ve, evidentemente, que se trata de una prosa descriptiva y, en más de una ocasión, no deja de traer inconfundible eco del estilo de Azorín. El detallismo de Estrada, sin embargo, no se revela siempre en los "primores de lo vulgar", sino en la descripción de los lujosos objetos de arte. Me basta un solo caso, en que se 
describen las piedras preciosas escondidas por los emperadores aztecas. Soñaba un aventurero ambicioso que los sacerdotes, vestidos de blanco, sacaban del lago joyas ricas:

Y el jade, de verde profundo como las esmeraldas, de verde claro como las hojas del álamo, apareció en las cuentas ensartadas en largos collares; los anillos de cobre, que hechos con delgados hilos de alambre, formaban minuciosas concepciones ornamentales; los vasos de ametistas para las pompas de los palacios, rútilos como el moaré de las aguas; las turquesas, que en profusas incrustaciones decoraban las carátulas de horribles gestos; las rojizas cornerinas; los ópalos con suaves palores de luna y las perlas, las perlas blancas, rosadas, negras y verdes (p. 54).

En las páginas del Visionario se observa una preferencia por la hora del crepúsculo, es decir el momento en que las cosas pierden su contorno, esfumándose y desrealizándose en la vaguedad de la penumbra. Significativo es el texto que ahora cito por varios motivos:

Allá abajo la ciudad ha perdido sus contornos; las gentes son sombras que se deslizan con apresuramiento; suena el ángelus; sube de las calles un sordo rumor de cosas que hablan y de cosas que ruedan; apenas en la serranía accidental hay una fulguración violeta que va ahogándose; las torres, las cúpulas, las almenas, se dibujan contra el cielo como siluetas en una pantalla (pp. 24-25).

Como se ve no sólo es importante la perspectiva sino que también se destaca la luz y su reflejo en las cosas. He aquí otro ejemplo: "Caía la tarde y el estrado se animaba cada vez más. Las luces del crepúsculo, al entrar por el amplio balcón, arrancaban vívidos chispeos al candil y a los capelos de cristal e iban a desfallecer dulcemente en el terciopelo de los arambeles"' (p. 30). En cambio, Estrada no deja de evocar la calma nocturna y la claridad de la luz lunar ("Nocturno de San Gerónimo", pp. 69-70), y en el convento se distingue la luz rojiza de una celda donde "a estas horas alguna monja jerónima debe de componer suaves endechas por el amor de Jesús" (p. 70). Al mismo tiempo Estrada demuestra a menudo una sensibilidad por las campanadas rítmicas de la ciudad colonial ("Las doce", pp. 91-92), y de la misma manera termina "El ángelus" con una percepción acústica:

Y fue como una acordada oración en la que llevaba la voz la Catedral y los demás templos decían las secuencias; y el vasto ru- 
mor del Ángelus flotaba en la tarde como la postrera nube de incienso elevada a Dios.

Y ya era la noche que avanzaba sus sombras cuando los últimos sones de las campanas recordaban a la ciudad silente el anuncio del ángel del Señor (p. 166).

Las transposiciones artísticas de la más variada procedencia embellecen la prosa de Estrada, constituyendo un adorno no excesivo, porque los recuerdos literarios y pictóricos son materia vital en las páginas del Visionario. A menudo la prosa en sí es pictórica, como puede observarse en el siguiente ejemplo y en otros ya citados:

Agrupados cerca de la vieja que en un taburete destacaba sus carnes flácidas, los niños se emocionaban de asombro y de miedo, y era aquél como un antiguo cuadro alemán en el que la luz del velón de cobre ponía sabiamente sombras y claridades intermitentes (p. 151).

En la misma viñeta ("El cuento", pp. 151-152) esa vieja refería a los niños un relato de espantos, en que un galeón que venía cargado de riquezas de España fue asaltado por los piratas, y al terminar la historia se apaga la luz del velón: "[ . . ] los niños temblaban en sus camastros y creían que el cuarto era una nave desolada en el oceáno, mientras que de fuera la tempestad los alucinaba con las rachas frías que se colaban por las junturas de la puerta, y tronaba el grito del rayo, que las campanas de la Soledad repercutían" (p. 152). Así el miedo interior de los niños se expresa también en los gestos amenazantes de la naturaleza exterior. En otro fragmento que tomo de un buen poema en prosa, "La casa" (pp. 191-192), se ve que el juego de luz y sonido contribuye a la representación del ambiente tranquilo de la noche: "Han dado las doce y ahora es la luna que va dibujando lacerías, arabescos y fantasmas, en el patio lleno de quietud y de silencio, como un cementerio"' (p. 192).

Los esquemas narrativos del Visionario, siempre diluidos, se fragmentan en pequeñas unidades independientes, cuya profusión contribuye con acierto a la totalidad del cuadro. Esa estructura, que se nutre del detalle mínimo, sería la más apta para los fines de Estrada, o sea la reconstrucción del ambiente en que pasaba de modo inalterable la vida de la Colonia. Pocas veces interviene en forma directa el yo del autor, pero transcribo ahora un ejem- 
plo en que sí figura la primera persona. Se oyen en la lejanía unas campanas y se apuntan las sensaciones interiores mediante una comparación de tipo sensorial: "Y siento como si las sábanas fuesen un sudario helado que a cada momento paraliza mis miembros'" (p. 144). Se percibe también el movimiento de las cortinas:

De pronto las cortinas de mi habitación se mueven, como si las hojas de la ventana se hubieran abierto y penetrado el aire. La luna ha ido a ocultarse detrás de la tapia y en el jardín el silencio se ha hecho más profundo. Oigo que unos pasos, lejanos y sordos, se han deslizado por la callejuela. Alguien debe pasar en estos momentos bajo la hornacina de las ánimas. El jardín ha quedado en tinieblas. Los ojos de la lechuza, sobre el ciprés, encienden sus fanales y las maderas de mi ventana crujen apenas, como si una mano sin fuerzas las hubiera empujado.

Yo hago la señal de la cruz (p. 144).

El fragmento que acabo de citar pertenece a "La alcoba", que es en el fondo un poema en prosa, cuyo estilo trae de inmediato un claro eco de la exquisita prosa del primer Valle-Inclán. Tanto los sonidos como las percepciones visuales trabajan para intensificar el sentido de misterio, a su vez condicionado por un sobretono religioso y la sugestión de la muerte. Y hasta en el ritmo la prosa de Estrada se parece a la del maestro español.

Por otra parte, una cosa notable en estas estampas es el humor y la ironía, así como la picardía, con que Estrada cuenta a su modo las peripecias de la Colonia. El buen sentido de humor, casi siempre presente, suele manifestarse por contraste e incongruencia, y sin duda algunos lectores toman en serio cosas escritas en broma por el ingenioso autor. Gracioso es el caso del Oidor orgulloso que ha muerto y cuyas exequias fueron celebradas en la tierra con gran pompa ceremoniosa. Llega al cielo, donde es recibido con total indiferencia por San Pedro, que no sabía nada en absoluto de la fama e importancia del engreído oidor, quien pensaba que Dios le esperaba en el cielo, donde iba a ser objeto de un magnífico recibimiento a todo lujo. Se le abre la puerta: “'[...] el oidor penetró, erguida la cabeza, con paso solemne. Fuera del portero ningún ser humano había allí; nadie lo esperaba; no resonó el golpe de alabarda; el paje no se presentaba, ni distinguíanse por todo aquello escaleras, galerías ni aposentos" (p. 35). Para no hacer mal papel que hubiera disminuido su alcurnia se sentó y comenzó a redactar sus memorias. En otro lugar, Estrada hace acumular en divertida hipérbole burlona todos 
los títulos habidos y por haber de cierto personaje noble de la corte ("La ronda", pp. 45-46), y es característico también que varios textos acaban con leve toque humorístico. Cito solamente dos ejemplos:

Y mientras que la madre sigue señalando los pasajes eminentes de Santa Elena, la señorita ha tirado de una tablilla disimulada en el fondo de su caja, y extrae de allí la miniatura en donde un caballero joven parece sonreírle sobre la firma que casi imperceptiblemente dice: Pacheco (p. 41).

Era el hijo de uno de los conquistadores de la Nueva España, nunca estuvo en la escuela de San Juan de Letrán, jamás dio un real para las obras piadosas, nunca visitó sus vastas tierras meridionales; pero tenía una casa de tezontle con treinta aposentos y en las hojas de roble de su magnificente portón las armas en relieve de sus antepasados, con un mote en latín que nunca pudo leer de corrido (p. 114).

El humor de Estrada no es nunca sarcástico e hiriente, nunca grosero ni maligno, pero él tiene una capacidad innata para ver el lado más risible de las cosas. Como se dijo, se burla de modo especial del erudito y del sabio. He aquí por un lado el venerable canónigo Landívar y Ceballos, "catalogador infatigable de la gloriosa literatura mexicana'” (p. 170), que había oído aquel día un violento sermón contra los insurgentes ("aún bullían en su imaginación las violentas metáforas en donde los revolucionarios eran llamados abortos de Satanás y desquiciadores del orden social" [ibid.]). Se decide a coronar su vida de erudito con la siguiente obra: Bibliografía Universal o Catálogo de todos los Autores y Libros Anónimos que no tratan ni aluden a la Milagrosa Aparición de la Santísima Virgen de Guadalupe (p. 171). Y por otro lado está el sabio que ha hecho minuciosas y exhaustivas investigaciones durante cincuenta años de labor fatigosa. A punto de morir, se resuelve a publicar los datos que tan pacientemente ha podido reunir. De su monumento de erudición, Del origen de los nahuatlacas, sólo pudo redactar los primeros renglones de su relación: "Si hemos de creer en los datos nebulosos que remotas tradiciones verbales nos ofrecen de manera incompleta..." (p. 124).

La inocente picardía de Genaro Estrada se manifiesta en distintas formas. Un buen ejemplo sería el de un fraile agustino sorprendido en su lectura por un padre vigilante. Éste le regaña por no haberse recogido como los otros hermanos de la comunidad. Se revela luego que el desvelado no leía el Sermonario de Fray 
Alonso de la Veracruz sino un libro mucho más peligroso: los $A d a$ gios de Erasmo. Termina la anécdota de la siguiente manera: "Ya llegaban las primeras luces del alba y todavía el fraile revolvíase en su lecho, sin haber descabezado ni un sueño, fatigado y sudoroso, como si allá debajo tuviera una parrilla que le asara las carnes y le chamuscara los cabellos"' (p. 74). En otro momento, visiblemente emocionada la virreina, Doña Ana de Mendoza, se había refugiado en algún aposento del palacio ("delataba su azoramiento con el trémulo palpitar de sus senos, que se diría iban a escaparse en una fuga de palomas medrosas", (p. 84) para leer un pliego escondido en un cajón secreto. Lo extrae, lo lee y se lo lleva: "La Virreina, ya con más calma, encaminóse hacia la puerta. Arriba de la cajonería el retrato del Marqués de Montesclaros era más grave y sus ajos parecían fulgurar de rabia"' (ibid.).

Finalmente, en la reconstrucción de la época colonial que se propone Estrada predominan dos vertientes características: la visión crítica y de burla por un lado; por otro, se impone una visión poética de la vida y el ambiente de aquellos tiempos pretéritos. E insistimos que Genaro Estrada sabe unir, en lograda síntesis, sus profundos conocimientos de la realidad de la Nueva España con una imaginación e inventiva que hacen de esta obra pequeña un precioso relicario de subido valor estético ${ }^{29}$.

\section{Epílogo: Pero Galín (1926) ${ }^{30}$}

El colonialismo cultivado por un nutrido grupo de escritores (Monterde, Abreu Gómez, Jiménez Rueda, Valle-Arizpe et al.) puede

29 Silvio ZaVala, en "Genaro Estrada y la historia de México", Letras de México, 1937, núm. 18, 1-2 y 10, clasifica el Visionario como literatura costumbrista y afirma con cierta severidad: "Hombre de crítica, análisis y humor, careció de las dotes imaginativas necesarias para destacar en este estilo. Pero su libro no es cansado y en ocasiones el lenguaje es bello aunque sin la plenitud del Pero Galín"' (p. 10); e insiste Zavala en que "son los párrafos críticos los de más enjundia: la adulación cortesana, el heredero fatuo, el orgulloso oidor y la gaceta colonial. No hay en las estampas de Estrada ningún momento de ingenuidad ni de descuido. Se aplicó a sí mismo la exigencia crítica de que era poseedor para hacer amena y aceptable su obra a los demás"' (ibid.).

30 De Pero Galín hay una buena edición moderna, la que publicó el INBA, (México, 1967), que lleva el ya citado prólogo de María del Carmen Millán (pp. vii-xxvi). A esta edición corresponden las páginas citadas de Estrada. También parece que Alfonso Reyes redactó un plan de prefacio destinado a una edición argentina de Pero Galín, pero no llegó a publicarse. 
explicarse, lógicamente, como una evasión de los azarosos tiempos revolucionarios. O, según otros, como rechazo de las modas europeizantes y los exotismos del modernismo. Al fin y al cabo, los colonialistas -escritores y críticos, historiadores y especialistas en el arte - se asomaban a lo mexicano con nuevas perspectivas. Dura poco la tendencia colonialista y sucumbe ante el empuje de la novela de la revolución, historia viva, en que solían participar sus autores. Es interesante notar que Francisco Monterde, él mismo colonialista, fue el que llamó la atención por primera vez sobre Los de abajo de Azuela ${ }^{31}$.

Aunque no me concierne aquí de manera directa la novelaensayo de Genaro Estrada, no puedo dejar de referirme brevemente a ella, porque el protagonista Pero Galín, coleccionista de antigüedades, tiene innegables rasgos característicos del mismo autor. Se trata, creo, de una obra que tiene mucho de autobiografía y, por tanto, de autocrítica ${ }^{32}$, puesto que Pero Galín es una estupenda burla del colonialismo como género literario. Por lo demás, al final, el protagonista parece darse cuenta de que ha sido un mero anacronismo en el mundo moderno de automóviles y estaciones de radio. En el último capítulo ("Aurora"), introducido de paso por un epígrafe tomado de El plano oblicuo de Reyes, se sugiere que el protagonista, transformado en ranchero y establecido en las afueras de México, ha amanecido a otra vida. Es decir, abandona sus manías coleccionistas y ya no se engaña con sueños utópicos que poco o nada valen en la vida práctica de hoy.

La acción novelesca es mínima, pero de gran interés son las páginas en que Estrada, con agudísimo sentido de humor, se ríe de los arcaísmos lingüísticos, dando también graciosas recetas para la fabla literaria (p. 13). Valoriza las tendencias estéticas de la época $\mathrm{y}$, de modo especial, el indigenismo cultivado por los escritores deseosos de ir al fondo de lo autóctono. En pintoresco recorrido de puestos y tendidos, el lector visita con Pero Galín el Volador

31 En una larga carta, Alfonso Reyes, dirigiéndose a Ermilo Abreu Gómez, comenta su obra El corcovado ( $A R O C$, t. 4, pp. 425-429) y le señala los peligros del arcaísmo al mismo tiempo que le pide que no persista en el género.

32 María del Carmen Millán [“"Prólogo"', p. xxiv] piensa que “el protagonista parece ser el propio Estrada en carácter e inclinaciones. En un juego un tanto cruel se aplica la autocrítica y se mofa primero de sí mismo y después de los extremos de una moda que había derivado en manía. Muy de acuerdo con su forma de ser, por otra parte, ya que tuvo fama de humorista, capaz de decir más que los otros y de poner a salvo su integridad con habilidad y sin prisa". 
y, con gran alarde erudito, se pasa revista a las chácharas, libros y objetos de arte tan buscados por los coleccionistas. En este contexto son significativos para el estudio de la guardarropía colonialista los "Intermedios" (pp. 53-82), fragmentos independientes que satirizan el colonialismo ya moribundo.

Así es que en más de un sentido esa novela miscelánea - ficción, autobiografía, ensayo, crónica literaria y lingüística - completa un determinado aspecto de la personalidad de Genaro Estrada, quien durante muchos años se dedicó a la organización de materiales dispersos del patrimonio cultural de México. Más tarde publicará sus libros de poesía y deja en el tintero otro libro de estampas, en el cual pensaba recoger sus impresiones de España bajo el título de Pasos de España.

Allen W. Phillips Universidad de California, Santa Barbara Emeritus 